\title{
Pattern of secretion of pregnancy-associated plasma protein-A (PAPP-A) during pregnancies complicated by fetal aneuploidy, in vivo and in vitro
}

Marie Clémence Leguy ${ }^{1}$, Stephanie Brun², Guillaume Pidoux ${ }^{3}$, Houria Salhi ${ }^{4}$, Agnes Choiset ${ }^{5}$, Marie Claude Menet ${ }^{1}$, Sophie Gil ${ }^{3,6,7}$, Vassilis Tsatsaris ${ }^{3,6,8}$ and Jean Guibourdenche ${ }^{1,3,6,7^{*}}$

\begin{abstract}
Background: Pregnancy-associated placental protein-A (PAPP-A) is a metalloprotease which circulates as an hetero-tetramer in maternal blood. Its maternal serum concentration in fetal trisomy 21 is decreased during the first trimester, so that PAPP-A is a useful screening biomarker. However, the regulation of PAPP-A placental secretion is unclear. We therefore investigated the secretion of PAPP-A in pregnancies complicated by fetal aneuploidies, both in vivo and in vitro.
\end{abstract}

Methods: Maternal serum collected between 10 WG and 33 WG during 7014 normal pregnancies and 96 pregnancies complicated by fetal trisomy 21, 18, and 13 were assayed for PAPP-A using the Immulite $2000 x p i$ system ${ }^{\circledR}$. The pregnancies were monitored using ultrasound scanning, fetal karyotyping and placental analysis. Villous cytotrophoblasts were isolated from normal and trisomic placenta and cultured to investigate PAPP-A secretion in vitro $(\mathrm{n}=6)$.

Results: An increased nuchal translucency during the first trimester is a common feature of many chromosomal defect but each aneuploidy has its own syndromic pattern of abnormalities detectable at the prenatal ultrasound scanning and confirmed at the fetal examination thereafter. PAPP-A levels rise throughout normal pregnancy whereas in trisomy 21, PAPP-A levels were significantly decreased, but only during the first trimester. PAPP-A levels were decreased in trisomy 13 and sharply in trisomy 18, whatever the gestational age. In vitro, PAPP-A secretion was decreased in aneuploidy, and associated with decreased hCG secretion in Trisomy 21 and 18. These biochemical profiles did not appear to be linked to any specific histological lesions affecting the placenta.

Conclusions: These profiles may reflect different quantitative and qualitative placental dysfunctions in the context of these aneuploidies.

Keywords: Pregnancy-associated placental protein-A, Villous cytotrophoblast, Maternal serum, Fetal trisomy, Ultrasound scanning, Placental dysfunction

\footnotetext{
* Correspondence: jean.guibourdenche@cch.aphp.fr

${ }^{1}$ Hormonology CHU Cochin AP-HP, 27 rue du Fbg St Jacques, Paris, France

${ }^{3}$ INSERM UMR 1139, 4 av de l'observatoire, Paris, France

Full list of author information is available at the end of the article
} 


\section{Background}

Pregnancy-associated placental protein-A (PAPP-A) was first isolated in the 1970s from the serum of pregnant women, and the synthesis of PAPP-A mRNA has since been demonstrated in numerous tissues $[1,2]$. PAPP-A is a metalloprotease belonging to the metzincin superfamily of zinc peptidase. It is active as a homodimer (dPAPP-A) which cleaves insulin-like growth factor binding proteins 4 and 5, thus regulating local IGF bioavailability and hence cell differentiation and proliferation $[3,4]$. dPAPP-A circulates at very low levels in non-pregnant women and men [5]. This dPAPP-A is abundantly expressed in unstable coronary atherosclerotic plaques and can be released in the event of rupture, thus rendering dPAPP-A a biomarker for coronary syndrome and unstable angina [6,7]. In pregnancy, PAPP-A is produced at high levels by the placenta and circulates as a covalent 2:2 heterotetrameric complex (htPAPP-A), designated PAPP-A/proMBP, with the proform of an eosinophil major basic protein (proMBP) that inhibits dPAPP-A proteasic activity [8]. Measurement of this complex is of interest in pregnancy $[9,10]$. Decreased levels are associated with adverse pregnancy outcomes such as intrauterine growth restriction (IUGR), preterm delivery, miscarriage and pre-eclampsia [10-12]. The principal routine value of PAPP-A is the prenatal screening of fetal aneuploidy, particularly for trisomy 21 which is often associated with low PAPP-A levels during the first trimester of pregnancy $[13,14]$. However, the patho-physiological mechanisms underlying this decrease are unclear and little is known about PAPP-A levels during the second and third trimesters of pregnancy in the event of fetal aneuploidy. Our aim was therefore to investigate the placental secretion of PAPP-A in vivo by characterising maternal levels of PAPP-A throughout pregnancy in the case of fetal aneuploidy (trisomy 21, trisomy 18 and trisomy 13) in a large cohort, and in vitro by culturing villous cytotrophoblasts isolated from aneuploid placentas.

\section{Methods}

\section{Maternal serum collection}

Maternal blood samples were collected prospectively according to the French policy on the screening of prenatal trisomy 21 at Port Royal Maternity Department Hospital, which is a reference centre for prenatal screening in Paris. This type of screening must be offered to every pregnant woman since 10 WG (weeks of gestation) [15]. Calculating the risk requires the measurement of nuchal translucency thickness (nt) and maternal serum markers i.e. pregnancy-associated plasma protein-A (PAPP-A) and the free $\beta$ subunit of chorionic gonadotrophin (hCG $\beta$ ) before 14WG; after that time point, hCG $\beta$ or total hCG and alphafoetoprotein (AFP) are determined, in combination with maternal age. The risk of T21was calculated using the Immulite 2000 automatic system and Prisca 4 software (Siemens ${ }^{\oplus}$ Typolog, Germany) [16]. Additional maternal blood samples collected at the time of pregnancy terminations in the cases of isolated major fetal abnormalities were included in the study (i.e.: cardiac or, renal or cerebral abnormalities of very poor prognosis). All blood samples were centrifuged for $10 \mathrm{~min}$. at $4000 \mathrm{G}$ at room temperature and then frozen until assay. We also reviewed fetal ultrasound profiles during the first trimester and after if available, fetal karyotyping when it was performed, and the immediate neonatal outcome. The overall population was divided into two groups: control pregnancies $(\mathrm{n}=$ 7014, pregnancies not associated with any maternal complication at the time of sampling and fetal aneuploidy) and pregnancies complicated by fetal aneuploidy $(n=96$ : trisomy $21 \mathrm{n}=68$, trisomy $18 \mathrm{n}=21$, and trisomy $13 \mathrm{n}=7$ ) from 10WG to 33WG. Among those cases of aneuploidy, 55 cases were fully documented (trisomy $21 \mathrm{n}=31$, trisomy $18 \mathrm{n}=21$, and trisomy $13 \mathrm{n}=3$ ).

\section{Foeto-placental examination and tissue collection}

French law allows for the termination of pregnancy with no gestational age limit when severe fetal abnormalities are observed. Placenta specimens were collected at the time of the termination of pregnancy and underwent macroscopic and microscopic examination. Pathologists analysed aneuploid placentas in 55 aneuploid cases at both the macroscopic level (i.e.: hypotrophy, immaturity, sponginess, hydropsy/ oedema, single umbilical artery), and histological level (principally hydropic villi, immature villi, post-mature villi, calcifications, fibrin deposits, trophoblastic cysts, bullous dystrophy) after being fixed in formalin, included in paraffin and stained with hemateineosin-saffron. Each item was graded ( 0 if absent, 1 if present, 2 if abundant) in order to establish a histological score. We were able to isolate villous cytotrophoblasts from fresh placentas for in vitro culture in three cases: one of trisomy 21 at $20 \mathrm{WG}$, one of trisomy 18 at 19WG and one of trisomy 13 at $18 \mathrm{WG}$, and three gestational agematched controls. Gestational age was confirmed by ultrasound measurement of the crown-rump length at 8-12 WG. Trisomy 21, 18 and 13 were diagnosed by karyotyping chorionic villi, amniotic fluid cells or fetal blood cells. In no case was aneuploidy due to translocation, and no mosaicism was observed.

\section{Cell cultures}

Cytotrophoblast cells were isolated after trypsin-Dnase I digestion and discontinuous Percoll gradient fractionation, as described by Kliman but with slight modifications $[17,18]$. Briefly, the villous sample was subjected to sequential enzymatic digestion in a solution containing $0.5 \%$ trypsin powder (W/V, Difco), $5 \mathrm{IU} / \mathrm{ml}$ DNAseI, $25 \mathrm{mM}$ HEPES, $4.2 \mathrm{mM} \mathrm{MgSO}_{4}$ and 1\% (W/V) 
penicillin/streptomycin (Biochemical industrie) in HBSS, with monitoring by light microscopy. The first digest, and in some cases the second digest, were discarded on the basis of the light microscopy findings, in order to eliminate any syncytiotrophoblast fragments. The cells contained in the four or five subsequent digests were purified on a discontinuous Percoll gradient (5\% to $70 \%$ in $5 \%$ steps). Cells that sedimented in the middle layer (density 1.048-1.062 g/ml) were further purified using a monoclonal anti-human leukocytic antigen A, B and C antibody (W6-32HL, Sera Lab, Crawley Down, UK). W6-32HL negative cytotrophoblast cells were diluted to a final density of $0.5 \times 10^{6} / \mathrm{ml}$ in Dulbecco's modified Eagle's medium (DMEM) containing 10\% foetal calf serum (FCS). After 4 hours of incubation at $37^{\circ} \mathrm{C}$ under $5 \% \mathrm{CO}_{2}$, non-adherent cells and syncytial fragments were removed by three efficient washes in culture medium. After 3 hours of culture, 95\% of cells isolated from full-term placentas were cytotrophoblastic cells, as shown by positive cytokeratin 7 staining with a specific monoclonal antibody (dilution 1:200, Dako). The cells were further cultured in $2 \mathrm{ml}$ of DMEM supplemented with $25 \mathrm{mM}$ HEPES, $2 \mathrm{mM}$ glutamine, 10\% heatinactivated FCS and antibiotics $(100 \mathrm{IU} / \mathrm{ml}$ penicillin and $100 \mathrm{mg} / \mathrm{ml}$ streptomycin) at $37^{\circ} \mathrm{C}$ under humidified $5 \%$ $\mathrm{CO}_{2}-95 \%$ air. The culture supernatants of aneuploid villous cytotrophoblasts were then integrated in the placental physiopole collections operated by the Perinatcollection project (ANR).

\section{PAPP-A assay}

PAPP-A concentrations in the maternal serum and culture medium were determined using the Immulite 2000 xpi automated chemiluminescent analyser ${ }^{\circledR}$ (Siemens, Germany) [16]. The IMMULITE 2000 PAPP-A assay is a solid-phase enzyme-labelled chemiluminescent immunometric assay that uses two monoclonal mouse antiPAPP-A antibodies. This assay was first standardized against the Brahms Kryptor PAPP-A assay. Its analytical sensitivity was $0.025 \mathrm{mU} / \mathrm{ml}$; the within- and betweenrun coefficients of variation were below $4 \%$ and $12 \%$, respectively, and the calibration range was $0-10 \mathrm{mU} / \mathrm{ml}$. Total hCG was also measured in culture medium as an index for formation of the endocrine syncytiotrophoblast using an Advia Centaur XP analyser (Siemens, Germany).

\section{Data analyses}

Statistical analysis were performed using the Statview F-4.5 software package (Abacus Concepts, Inc., Berkeley, CA, USA). Values are expressed as crude values and 10ciles, 50ciles, 90ciles values. Significant differences $(\mathrm{p}<0.05)$ were identified using the non parametric KruskalWallis and Mann-Whitney U tests.

\section{Results}

Ultrasound scanning characteristics of fetal aneuploidies In the 55 cases fully documented, ultrasound scanning is informative from the first trimester, particularly in trisomy $18(17 / 21 ; 81 \%)$ (see Additional file 1, Table 1). Around one third of the trisomic 18 fetuses presented at least two associated abnormal signs at ultrasound scanning. The most frequent signs were enlarged nt, exomphalos and cystic hygroma. Other signs tend to become detectable during the second and third trimesters of pregnancy, mainly in the case of Trisomy 21 even if there were not particularly associated with any type of aneuploidy.

\section{Maternal serum PAPP-A levels during the course of pregnancy}

PAPP-A levels rise throughout a normal gestation from $2.3 \mathrm{mU} / \mathrm{mL}$ at $10 \mathrm{WG}$ to $56 \mathrm{mU} / \mathrm{ml}$ at $24 \mathrm{WG}$ and reaches $103 \mathrm{mU} / \mathrm{mL}$ at 33WG (Figure 1). There is a sharp, 24-fold increase $(p=0.01)$ between the end of the first trimester

Table 1 Common sonographic defects in aneuploides fetuses

\begin{tabular}{|c|c|c|c|}
\hline & $\begin{array}{l}\text { Trisomy } 21 \\
(\mathrm{n}=31)\end{array}$ & $\begin{array}{l}\text { Trisomy } 18 \\
(\mathrm{n}=21)\end{array}$ & $\begin{array}{l}\text { Trisomy } 13 \\
(\mathrm{n}=3)\end{array}$ \\
\hline \multicolumn{4}{|l|}{ 1rst trimester } \\
\hline Cystic hygromata & 2 & 3 & 0 \\
\hline Enlarged NT ( $\geq 3.5$ mm) & 14 & 9 & 0 \\
\hline Hydrops & 0 & 1 & 0 \\
\hline Cardiac abnormalities & 0 & 2 & 1 \\
\hline Encephalocele & 0 & 2 & 0 \\
\hline Spina bifida & 0 & 2 & 0 \\
\hline Exomphalos & 0 & 5 & 1 \\
\hline \multicolumn{4}{|l|}{$2 \mathrm{~d}$ and $3 \mathrm{~d}$ trimester } \\
\hline Choroid plexus cysts & 1 & 2 & 0 \\
\hline Other brain abnormalities & 1 & 0 & 1 \\
\hline Skull and face abnormalities & 1 & 1 & 0 \\
\hline Cardiac abnormalities & 3 & 2 & 1 \\
\hline Digestive atresia & 1 & 1 & 0 \\
\hline Hepatic calcifications & 1 & 0 & 0 \\
\hline Renal abnormalities & 0 & 1 & 0 \\
\hline Ascite & 0 & 1 & 0 \\
\hline Extremities abormalities & 1 & 1 & 1 \\
\hline Short femur & 1 & 1 & 0 \\
\hline Macrosomia or hypotrophia & 1 & 1 & 0 \\
\hline Fetal death & 0 & 1 & 0 \\
\hline $\begin{array}{l}\text { Decrease or increased amniotic } \\
\text { fluid volume }\end{array}$ & 4 & 2 & 1 \\
\hline
\end{tabular}

Ultrasound scanning was performed by experimented operators at the first, the second and the third trimester on 55 fetuses which were thereafter diagnosed trisomic 21, trisomic 18 and trisomic 13 diagnosed by karyotyping chorionc villi, amniotic fluid cells or fetal blood cells. 


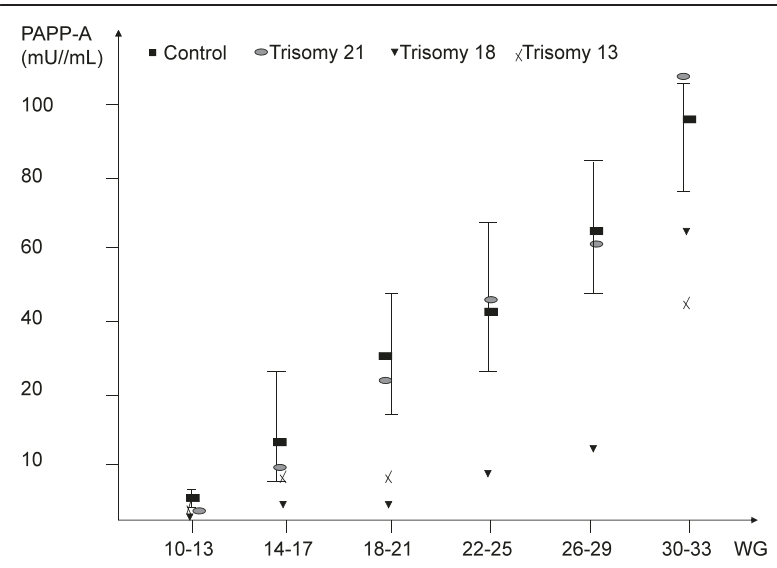

Figure 1 Maternal serum levels of PAPP-A throughout normal gestation and in gestations complicated by fetal aneuploidy. PAPP-A was measured using the assay developed on the Immulite 2000 analyser (Siemens, Germany) specific for the heterotetrameric complex (htPAPP-A) in the maternal serum of 7014 normal pregnancies (controls) and 96 pregnancies affected by fetal trisomy (68 trisomy 21, 21 trisomy 18, 7 trisomy 13) from 10WG to 33WG. Results are expressed in median values, and 10-90ciles for the controls.

and the end of the second trimester, followed by a slower, 2-fold increase from the end of the second trimester until delivery. In trisomy 21 PAPP-A levels compared with the controls were significantly decreased at the end of the first trimester (median value: $2.7 \mathrm{mU} / \mathrm{mL}, \mathrm{p}=0.02$ ) but not thereafter $(45.8 \mathrm{mU} / \mathrm{mL}$ at the end of the second trimester and $120 \mathrm{mU} / \mathrm{mL}$ near the term). In trisomy 18 and trisomy 13, maternal PAPP-A levels were always significantly lower $(\mathrm{p}<0.01$ and $\mathrm{p}=0.02$ respectively) than in the controls whatever the gestational age. PAPP-A levels were particularly low in trisomy 18 (median value: $0.9 \mathrm{mU} / \mathrm{mL}$ at the end of the first trimester, $9.7 \mathrm{mU} / \mathrm{mL}$ at the end of the second trimester and $67.7 \mathrm{mU} / \mathrm{mL}$ near the term)

\section{In Vitro secretion of PAPP-A and hCG by villous trophoblastic tissue}

We measured the PAPP-A and total hCG secreted in vitro by villous cytotrophoblasts during their differentiation into syncytiotrophoblast. In the controls, PAPP-A and hCG levels increased concomitantly with the formation of syncytiotrophoblast from 24 to 72 hours of culture, by 10 and 20-fold respectively. hCG secretion was significantly decreased in trisomy 18 and to a lesser extent in trisomy 21 but not in trisomy 13 . The secretion of PAPP-A was significantly very low $(<1 \mathrm{mU} / \mathrm{mL}$, $\mathrm{p}=0.01$ ) in the context of any aneuploidy, with no increase during the culture (Figure 2).

\section{Placental histology}

Investigations were performed in 55 patients (see Additional file 2, Table 2). Although it was inconsistent, the placenta was macroscopycally rather small $(28 / 55,51 \%)$ and abnormal $(44 / 55,80 \%)$. In trisomy 21 and trisomy 18 , it presented an abnormal mesenchymal core and abnormal trophoblastic tissue when compared to age matched controls (Figure 3). Indeed, the placental villi displayed an important immaturity $(26 / 55,47 \%)$ with an increased mean villous diameter and stromal hydrops; a reduction in the number of vessels; a trophoblastic tissue irregular associating a hypoplasic syncytium with a persisting double layer of villous cytotrophoblasts. These cytotrophoblasts were lying on frequent fibrin deposits $(16 / 55,29 \%)$, calcifications $(10 / 55,18 \%)$, hydropic areas $(49 / 55,89 \%)$ and basophil infiltrates. Hydropic villi and calcifications were also observed in trisomy 13. A single umbilical artery and of trophoblastic cysts were only noted in the context of trisomy 18 whereas bullous dystrophy was only noted in the context of trisomy 21 . No abnormality was specific of trisomy 13 . The median histological scores were 6 for Trisomy 21 and 5 for Trisomy 18 (data not shown).

\section{Discussion}

This work confirms the value of combining an early determination of maternal serum markers such as PAPP-A with prenatal ultrasound scanning in order to detect fetal aneuploidy [19-21]. Indeed, phenotypic abnormalities exist in both trisomic fetuses and the placenta $[22,23]$. The anatomical differences between the controls and trisomic patients are significant enough to be detected in vivo using prenatal ultrasound scans. Post-mortem examinations of affected fetuses have confirmed such differences [24].

As expected, during the first trimester, a common feature of many chromosomal defects is increased nuchal translucency [25]. However, our work has shown that each chromosomal defect tended to have its own syndromic pattern of abnormalities that affect the skull and brain, the face and neck, the chest, abdomen and extremities [26].

Although ultrasound scans can demonstrate that major chromosomal defects are often associated with multiple fetal abnormalities, maternal serum markers may provide valuable additional information [26]. We confirm here in a large cohort that fetal aneuploidies, are generally associated with decreased PAPP-A levels in maternal serum [27-29]. This reduction was limited to the first trimester of pregnancy in trisomy 21 where as it became significative in the second half of pregnancy in case of trisomy 13 . We were able to establish that it persists throught the gestation in trisomy 18. These biochemical profiles did not appear to be linked to any specific histological lesions affecting the placenta. The present study has thus confirmed that in a context of aneuploidy, the villi are mainly immature, hydropic and poorly vascularised, with fibrin 


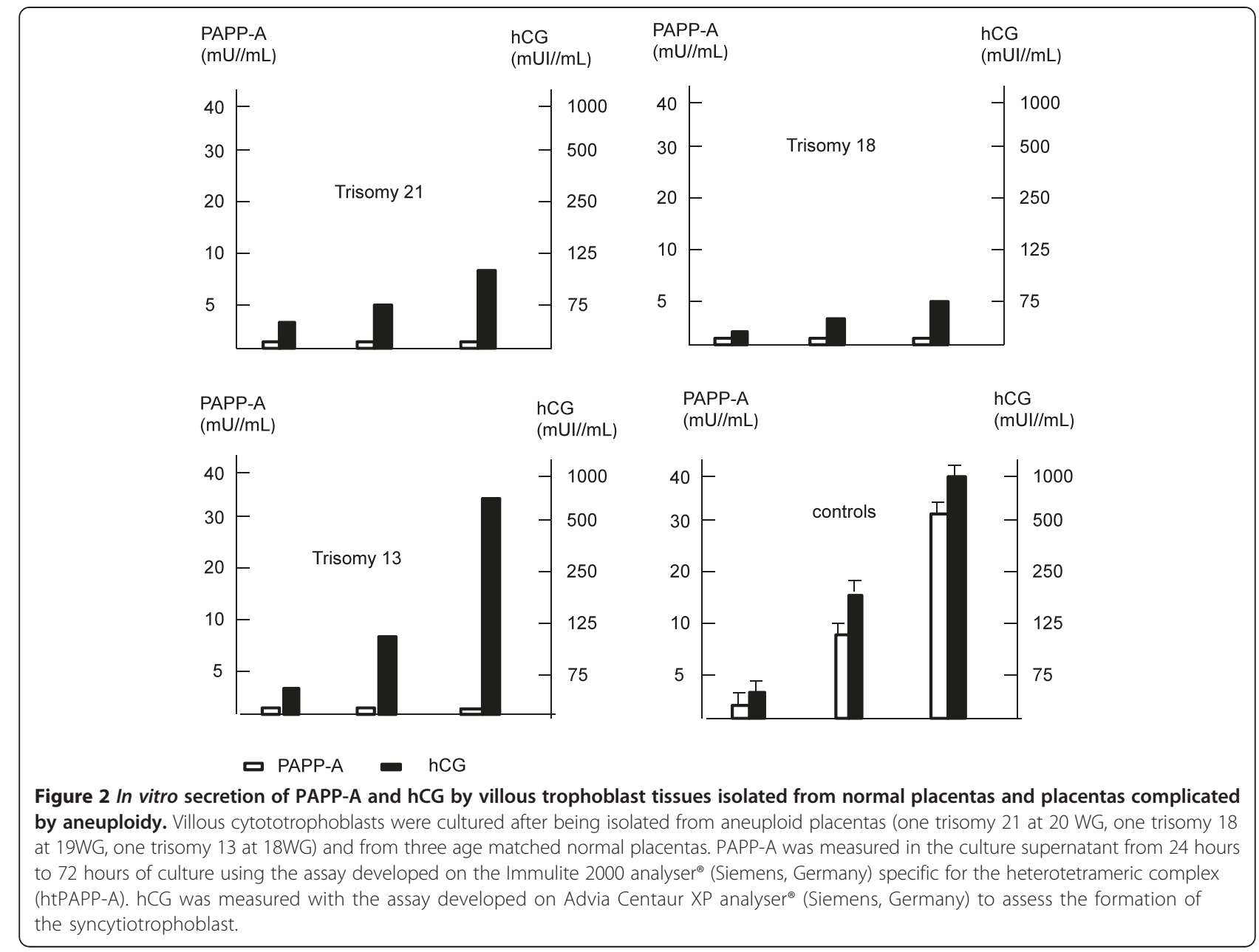

Table 2 Principal macroscopic and microscopic findings regarding placentas complicated by aneuploidy

\begin{tabular}{llll}
\hline & $\begin{array}{l}\text { Trisomy } \\
(\mathbf{n}=\mathbf{3 1})\end{array}$ & $\begin{array}{l}\text { Trisomy } \mathbf{1 8} \\
(\mathbf{n}=\mathbf{2 1})\end{array}$ & $\begin{array}{l}\text { Trisomy 13 } \\
(\mathbf{n}=\mathbf{3})\end{array}$ \\
\hline Macroscopy & 16 & 12 & 0 \\
Hypotrophy & 24 & 14 & 0 \\
Immaturity & 20 & 10 & 0 \\
Sponginess & 24 & 20 & 0 \\
Hydropsy & 0 & 4 & 0 \\
Single umbilical artery & & & \\
Histology & 28 & 19 & 2 \\
Hydropic villi & 20 & 6 & 0 \\
Immature villi & 12 & 6 & 0 \\
Post-mature villi & 4 & 4 & 2 \\
Calcifications & 12 & 4 & 0 \\
Fibrin deposits & 0 & 4 & 0 \\
Trophoblastic cysts & 8 & 0 & 0 \\
Bullous dystrophy & & &
\end{tabular}

deposits but with large variability [30-34]. The trophoblastic tissue is poorly developed with a thin syncytiotrophoblast and the persistence of a double layer of villous cytotrophoblasts. The patterns of trisomic placental villi is known to change between the first and second trimesters of pregnancy. During the second trimester, trisomic villi were predominantly large, irregular and hypovascular, while during the third trimester, this type of villus abnormality was only observed in a few villi and was associated with focal hypervascularity.

It is likely that the decrease in PAPP-A levels is not directly related to the chromosomal defect because the PAPP-A gene is located on human chromosome 9 and not on chromosomes 21,18 or 13 . The protein is secreted as an active dPAPP-A homodimer in the form of a metalloproteinase which both interacts with the extracellular matrix and cleaves IGFBP-4 and 5, thus increasing the local bioavailability of IGFs [2-4,8,35-38]. It has different features that allows PAPP-A to interact with laminin, complement and heparin sulphates on the cell 


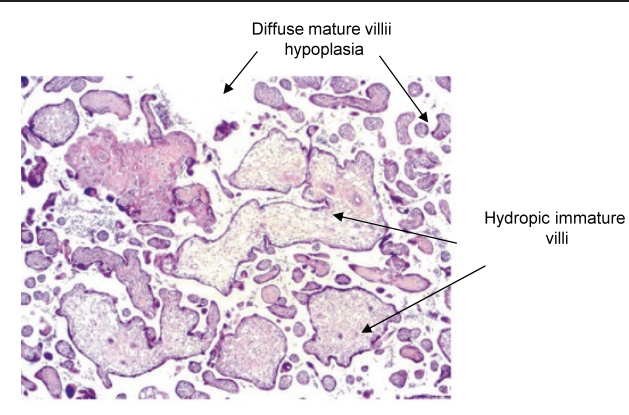

Trisomy 21
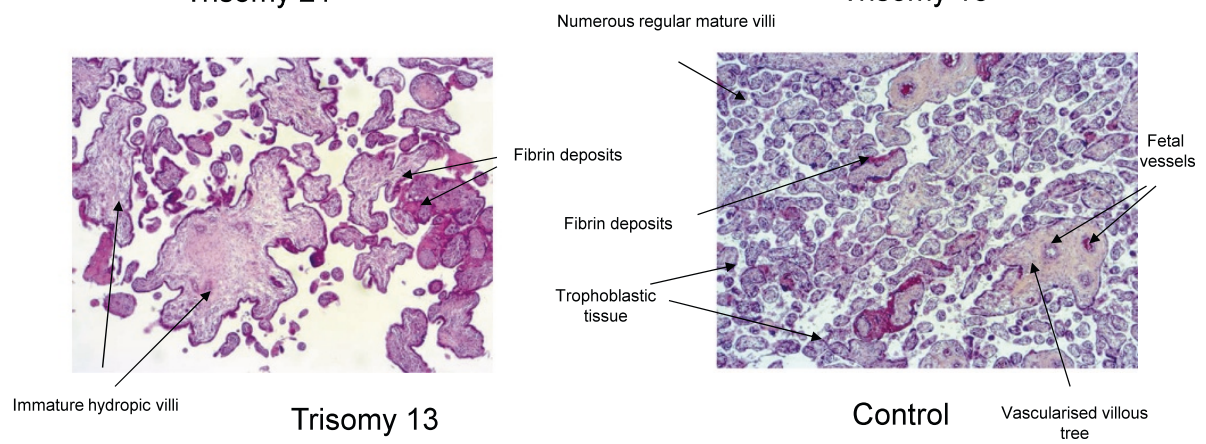

Figure 3 Microscopic analysis of placental villi in normal pregnancy and pregnancy complicated by aneuploidy. After termination of pregnancy, 55 aneuploid placentae were analysed by experimented pathologists at the macroscopic level, and the histological level after being fixed in formalin, included in paraffin and stained with hematein-eosin-saffron. Mature villi i.e. small diameter, strong staining, presence of fetal vessels, decreased connective tissue, covered by trophoblastic tissue. Immature hydropic villi i.e. large diameter, pale staining, few fetal vessels, connective tissue, decreased trophoblastic tissue.

surface and in the extra-cellular matrix. During pregnancy, almost all circulating PAPP-A is bound covalently to a glycoprotein, proMBP (preform of eosinophil major basic protein) to form a hetero-tetrameric complex composed of two PAPP-A and two proMBP subunits [39]. We were able to establish the maternal profile of htPAPP-A first using antibodies specific to this complex, and second not only during the first trimester but also during the second and third trimesters. We confirmed the sharp increase of PAPP-A during the first half of pregnancy, which has been suggested to reflect the increase in placental volume, and we showed that the slope of this increase rose very slowly during the second half of pregnancy [40-42]. However, very little is known as yet about the individual secretion profiles of dPAPP-A and proMBP [43]. The latter is believed to occupy the cell-surface binding site of PAPP-A in the circulating complex, so that the tetramer can't bind to the cell surface when it enters the maternal circulation. APAPP-A and proMBP, and the htPAPPA heterotetrameric complex are expressed physiologically in the villous trophoblast of the first and third trimesters [4,44-47]. dPAPP-A is weakly expressed in the ST at full-term, whereas htPAPP-A displays the opposite pattern. We had previously explored the pattern of PAPP-A secretion by the villous trophoblast in vitro, showing that this secretion increased in line with formation of the endocrine syncytiotrophoblast [48]. During the present study, we investigated the pattern of PAPP-A secretion by the aneuploid villous trophoblast. Our preliminary results suggest that in the case of aneuploidy, the villous trophoblast secretion of PAPP-A was altered. In the case of trisomy 18, we observed an in vitro decrease in hCG and PAPP-A secretion, and in vivo a small placental mass and syncytial mass. We also established in vivo that in trisomy 18, decreased maternal serum PAPP-A levels were not restricted to the first part of pregnancy. Thus, low maternal PAPP-A levels levels are likely to reflect both a reduction in placental volume and lower levels of trophoblastic secretion [49-51]. In trisomy 13, as the placental mass is normal, we can speculate that the decreased maternal serum PAPP-A levels we observed all along the pregnancy result predominantly from a defective trophoblastic production. In trisomy 21 , we confirmed our previous in vitro findings regarding defective differenciation of villous cytotrophoblasts into a syncytiotrophoblast [52]. This led to the decreased PAPPA secretion we observed. However, we confirmed that in vivo, maternal serum PAPP-A levels were decreased but only in the first trimester of pregnancy. Thus, the mechanisms involved may be more complex and may differ from one aneuploidy to another [53]. 
This PAPP-A decrease seems to be related to a global an impairment of satisfactory differentiation of the villous cytotrophoblast but also of the extravillous cytotrophoblast Indeed, because the decrease in PAPP-A levels is observed early in any pregnancy associated to fetal aneuploidy, the defect may concern the extravillous cytotrophoblast, which is the principal source of PAPP-A at this stage. We had previously demonstrated in vitro changes to the patterns of PAPP-A secretion, to their regulation during normal gestation and to the trophoblastic phenotype, i.e. villous cytotrophoblast or extravillous cytotrophoblast [54]. Further studies are now necessary to focus on aneuploid extravillous cytotrophoblasts, but some findings have suggested defective differentiation along the invasive pathway that can affect not only PAPP-A but also other proteases (i.e. MM-9, ADAM12) $[55,56]$. This could explain why these proteases have been proposed as biomarkers of aneuploidy [57]. It is likely that not only the trophoblastic cells but all cells in the villi could turned over and be differentially modified in the context of aneuploidy $[30,58,59]$.

\section{Abbreviations}

AFP: Alphafoetoprotein; hCG: Chorionic gonadotrophin; PAPP-A: Pregnancyassociated placental protein-A; WG: Weeks of gestation.

\section{Competing interests}

The authors declare that they have no competing interests.

\section{Authors' contributions}

MCL carried out immunoassays and helped to draft the manuscript. SB collected all the clinical data and helped to draft the manuscript. GB perfomed the in vitro cultures of villous cytotrophoblast, HS perfomed placenta histology analysis, AC performed foetal karyotyping, MCM helped to draft the manuscript, SG participated in results analysis and discussion, $V T$ participated in the design of the study and the collection of clinical data. JG conceived the study, analysed the results and performed the statistical analysis, wrote the article. All authors read and approved the final manuscript.

\section{Acknowledgments}

We thanks Dominique Perrin and Frederic Laujay (Siemens Diagnostics, France), Benoit Toro, Catherine Gaillard, Pauline Gregoire and Floriane Pereira (Hormonology CHU Cochin APHP France) for their technical assistance. This work was supported by L'Agence Nationale de la Recherche (ANR), action "Equipement d'excellence" Equipex 10-PhC/SC-11/243, project "Perinatcollection".

\section{Author details}

${ }^{1}$ Hormonology CHU Cochin AP-HP, 27 rue du Fbg St Jacques, Paris, France. ${ }^{2}$ Maternity CHU Bordeaux, Place Amélie Raba-Léon, Bordeaux, France. ${ }^{3}$ INSERM UMR 1139, 4 av de l'observatoire, Paris, France. ${ }^{4}$ Foeto-pathology $\mathrm{CHU}$ Cochin AP-HP, 27 rue du Fbg St Jacques, Paris, France. ${ }^{5}$ Cytogenetic CHU Cochin AP-HP, 27 rue du Fbg St Jacques, Paris, France. ${ }^{6}$ PremUp foundation, 27 rue du Fbg St Jacques, Paris, France. 'Faculté de Pharmacie, Université Paris Descartes, 4 av de l'observatoire, Paris, France. ${ }^{8}$ Maternity CHU Cochin AP-HP, 27 rue du Fbg St Jacques, Paris, France.

Received: 21 September 2014 Accepted: 12 December 2014 Published: 28 December 2014

\section{References}

1. Lin TM, Halbert SP, Kiefer D, Spellacy WN, Gall S: Characterization of four human pregnancy-associated plasma proteins. Am J Obstet Gynecol 1974 118:223-236.
2. Overgaard MT, Oxvig C, Christiansen M, Lawrence JB, Conover CA, Boldt HB, Olsen IM, Laursen LS, Gleich GJ, Sottrup-Jensen L, Haaning J: Messenger acid levels of pregnancy associated plasma protein $A$ and the proform of eosinophil major basic protein: expression in human reproductive and non reproductive tissues. Biol Reprod 1999, 61:1083-9108.

3. Giudice LC, Conover CA, Bale L, Faessen GH, Ilg K, Sun I, Imani B, Suen LF, Irwin JC, Christiansen M, Overgaard MT, Oxvig C: Identification and regulation of IGFBP-4 protease and its physiological inhibitor in human trophoblasts and endometrial stroma: evidence for paracrine regulation of IGF-II bioavailability in the placental bed during human implantation. J Clin Endocrinol Metab 2002, 87:1359-1366.

4. D'Elia P, Marzioni D, Castellucci M, Mocci C, Pala A: Homodimeric pregnancy-associated plasma protein-A in normal human placenta of first and third trimester of pregnancy: biochemical and morphological observations. Placenta 2012, 33:942-945.

5. Coskun A, Serteser M, Duran S, Inal TC, Erdogan BE, Ozpinar A, Can O, Unsal I: Reference interval of pregnancy-associated plasma protein-a in healthy men and non-pregnant women. J Cardiol 2013, 61:128-131.

6. Bayes-Genis A, Conover CA, Overgaard MT, Bailey KR, Christiansen M, Holmes DR, Virmani R, Oxvig C, Schwartz RS: Pregnancy-associated plasma protein A as a marker of acute coronary syndromes. N Engl J Med 2001, 345:1022-1029.

7. Consuegra-Sanchez L, Fredericks S, Kaski JC: Pregnancy-associated plasma protein-A (PAPP-A) and cardiovascular risk. Atherosclerosis 2009, 203:346-352.

8. Oxvig C, Sand O, Kristensen T, Gleich GJ, Sottrup-Jensen L: Circulating human pregnancy-associated plasma protein $\mathrm{A}$ is disulfide-bridged to the proform of eosinophil major basic protein. J Biol Chem 1993, 268:12243-12246.

9. Westergaard JG, Teisner B, Chemnitz J, Grudzinkas JG: Serum PAPP-A in normal pregnancy: relationship to fetal and maternal characteristics. Arch Gynecol 1983, 233:211-215.

10. Kirkegaard I, Uldbjerg N, Oxvig C: Biology of pregnancy-associated plasma protein-A in relation to prenatal diagnostics: an overview. Acta Obstet Gynecol Scand 2010, 89:1118-1125.

11. Dugoff L, Hobbins JC, Malone FD, Porter TF, Luthy D, Comstock CH Hankins G, Berkowitz RL, Merkatz I, Craigo SD, Timor-Tritsch IE, Carr SR, Wolfe HM, Vidaver J, D'Alton ME: First trimester maternal serum PAPP-A and free-beta subunit human chorionic gonadotropin concentrations and nuchal translucency are associated with obstetric complications: a population-based screening study (the FASTER Trial). Am J Obstet Gynecol 2004, 191:1446-1451.

12. Ranta JK, Raatikainen K, Romppanen J, Pulkki K, Heinonen S: Decreased PAPP-A is associated with preeclampsia, premature delivery and small for gestational age infants but not with placental abruption. Eur J Obstet Gynecol Reprod Biol 2011, 157:48-52.

13. Bersinger NA, Brizot ML, Johnson A, Snijders RJ, Abbott J, Schneider H, Nicolaides KH: First trimester maternal serum pregnancy-associated plasma protein A and pregnancy-specific $\beta 1$-glycoprotein in fetal trisomies. Br J Obstet Gynaecol 1994, 101:970-974.

14. Haddow JE, Palomaki GE, Knight GJ, Williams J, Miller WA, Johnson A: Screening of maternal serum for fetal Down's syndrome in the first trimester. N Engl J Med 1998, 338:955-961.

15. Ville Y: How to improve the screening and diagnosis of fetal aneuploidy? Bull Acad Med 2005, 189:1773-1784.

16. Spencer K: First trimester maternal serum screening for Down's syndrome: an evaluation of the DPC Immulite 2000 free beta-hCG and pregnancy protein-A assays. Ann Clin Biochem 2005, 42:30-40.

17. Klinman HJ, Nestler JE, Sermasi E, Sanger JM, Strauss JF: Purification, characterization, and in vitro differentiation of cytotrophoblasts from human term placentae. Endocrinology 1986, 118:1567-1582.

18. Guibourdenche J, Alsat E, Soncin F, Rochette-Egly C, Evain-Brion D: Retinoid receptors expression in human term placenta: involvement of RXR alpha in retinoid induced-hCG secretion. J Clin Endocrinol Metab 1998, 83:1384-1387.

19. Spencer K, Souter V, Tul N, Snijders R, Nicolaides KH: A screening program for trisomy 21 at 10-14 weeks using fetal nuchal translucency, maternal serum free beta-human chorionic gonadotropin and pregnancy associated plasma protein A. Ultrasound Obstet Gynecol 1999, 13:231-237.

20. Grande M, Arigita M, Borobio V, Jimenez JM, Fernandez S, Borrell A: First trimester detection of structural abnormalities and the role of aneuploidy markers. Ultrasound Obstet Gynecol 2012, 339:157-163.

21. Shiefa S, Amargandhi M, Bhupendra J, Moulali S, Kristine T: First trimester maternal screening using biochemical markers PAPP-A and free $\beta$-hCG 
for Down Syndrome, Patau Syndrome and Edward Syndrome. Indian J Clin Biochem 2013, 28:3-12.

22. Smith-Bindman R, Hosmer W, Feldstein VA, Deeks JJ, Goldberg JD: Secondtrimester ultrasound to detect fetuses with Down syndrome: a metaanalysis. JAMA 2001, 85:1044-1055.

23. Lai S, Lau WL, Leung WC, Lai FK, Chin R: Is ultrasound alone enough for prenatal screening of trisomy 18 ? A single center experience in 69 cases over 10 years. Prenat Diagn 2010, 30:1094-1099.

24. Szigeti Z, Csaba A, Pete B, Hajdú J, Papp Z, Papp C: Correlation of prenatal sonographic diagnosis and morphologic findings of fetal autopsy in fetuses with trisomy 21. J Ultrasound Med 2007, 26:61-68.

25. Jemmali M, Valat AS, Poulain P, Favre R, Bourgeot P, Subtil D, Puech F: Nuchal tranlucency: screening for chromosomal abnormalities and congenital malformations. Multicenter study. I Gynecol Obstet Biol Reprod 1999, 28:538-543.

26. Nicolaides KH: Screening for fetal anuploidies at 11 to 13 weeks. Prenat Diagn 2011, 31:7-15.

27. Tul N, Spencer K, Noble P, Chan C, Nicolaides K: Screening for trisomy 18 by fetal nuchal translucency and maternal serum free beta-hCG and PAPP-A at 10-14 weeks of gestation. Prenat Diagn 1999, 19:1035-1042.

28. Spencer K, Nicolaides KH: A first trimester trisomy 13/trisomy 18 risk algorithm combining fetal nuchal translucency thickness, maternal serum free $B$-hCG and PAPP-A. Prenat Diagn 2002, 22:877-879.

29. Nicolaides KH, Spencer K, Avgidou K, Faiola S, Falcon O: Multicenter study of first-trimester screening for trisomy 21 in 75821 pregnancies: results and estimation of the potential impact of individual risk-orientated twostage first-trimester screening. Ultrasound Obstet Gynecol 2005, 25:221-226.

30. Jauniaux $\mathrm{E}$, Hustin $\mathrm{J}$ : Chromosomally abnormal early ongoing pregnancies: correlation of ultrasound and placental histological findings. Hum Pathol 1998, 29:1195-1199.

31. Labbé S, Copin H, Choiset A, Girard S, Barbet JP: The placenta and trisomies 13, 18, 21. J Gynecol Obstet Biol Reprod 1989, 18:989-996.

32. Rochelson B, Kaplan C, Guzman E, Arato M, Hansen K, Trunca C: A quantitative analysis of placental vasculature in the third trimester fetus with autosomal trisomy. Obstet Gynecol 1990, 75:59-63.

33. Roberts L, Sebire NJ, Fowler D, Nicolaides KH: Histomorphological features of chorionic villi at 10-14 weeks of gestation in trisomic and chromosomally normal pregnancies. Placenta 2000, 21:678-683.

34. Queshsri F, Jacques SM, Johnson MP, Hume RF, Kramer RL, Yaron Y, Evans MI: Trisomy 21 placentas: histopathological and immunohistological finding using proliferating cell nuclear antigen. Fetal Diagn Ther 1997, 12:210-215.

35. Kristensen T, Oxvig C, Sand O, Moller L, Sottrup-Jensen GJ: Amino acid sequence of human pregnancy-associated plasma protein $\mathrm{A}$ derived from cloned cDNA. Biochemistry 1994, 33:1592-1598.

36. Overgaard MT, Haaning J, Boldt HB, Olsen IM, Laursen LS, Christiansen M, Gleich GJ, Sottrup-Jensen L, Conover CA, Oxvig C: Expression of recombinant human pregnancy-associated plasma protein-A and identification of the proform of eosinophil major basic protein as its physiological inhibitor. $J$ Biol Chem 2000, 275:31128-31133.

37. Laursen LS, Overgaard MT, Soe R, Boldt HB, Sottrup-Jensen L, Giudice LC, Conover CA, Oxvig C: Pregnancy-associated plasma protein-A (PAPP-A) cleaves insulin-like growth factor binding protein (IGFBP)-5 independent of IGF: implications for the mechanism of IGFBP-4 proteolysis by PAPP-A. FEBS Lett 2001, 504:36-40.

38. Lawrence JB, Oxvig C, Overgaard MT, Sottrup-Jensen L, Gleich GJ, Hays LG, Yates JR, Conover CA: The insulin-like growth factor (IGF)-dependent IGF binding protein- 4 protease secreted by human fibroblasts is pregnancyassociated plasma protein A. Proc Natl Acad Sci U S A 1999, 96:3149-3153.

39. Oxvig C, Sand O, Kristensen T, Kristensen L, Sottrup-Jensen L: Isolation and characterization of circulating complex between human pregnancyassociated plasma protein $\mathrm{A}$ and proform of eosinophil major basic protein. Biochim Biophys Acta 1994, 1201:415-423.

40. Bischof P, Duberg S, Herrmann WL, Sizonenko PC: Amniotic fluid and plasma concentrations of pregnancy-associated plasma protein $\mathrm{A}$ (PAPP-A). Br J Obstet Gynaecol 1982, 89:701-703.

41. Lin TM, Halbert SP, Kiefer D, Spellacy WN: Measurement of pregnancy associated plasma proteins during human gestation. J Clin Invest 1974, 54:576-582.

42. Folkersen J, Grudzinskas JG, Hindersson P, Teisner B, Westergaard J: Pregnancy-associated plasma protein $A$ : circulating levels during normal pregnancy. Am J Obstet Gynecol 1981, 139:910-924.
43. Pihl K, Larsen T, Rasmussen S, Krebs L, Christiansen M: The proform of eosinophil major basic protein: a new maternal serum marker for adverse pregnancy outcome. Prenat Diagn 2009, 29:1013-1019.

44. Tornehave D, Chemnitz J, Teisner B, Folkersen J, Westergaard JG Immunohistochemical demonstration of pregnancy associated plasma protein A (PAPP-A) in the syncytiotrophoblast of the normal placenta at different gestational ages. Placenta 1984, 5:427-431.

45. Schindler AM, Bordignon P, Bisch of P: Immunohistochemical localization of pregnancy-associated plasma protein A in decidua and trophoblast: comparison with human chorionic gonadotrophin and fibrin. Placenta 1984, 5:227-236

46. Chemnitz J, Folkersen J, Teisner B, Sinosich MJ, Tornehave D, Wetergaard JG Bolton AE, Grudzinkas JG: Comparison of different antibody preparations against pregnancy-associated plasma protein A (PAPP-A) for the use in localization and immunoassay studies. Br J Obstet Gynaecol 1986, 93:916-923.

47. Bonno M, Oxvig C, Kephart GM, Wagner JM, Kristensen T, Sottrup-Jensen L, Gleich GJ: Localization of pregnancy-associated plasma protein A and colocalization of pregnancy-associated plasma protein A messenger ribonucleic acid and eosinophil granule major basic protein messenger ribonucleic acid in placenta. Lab Invest 1994, 71:560-566.

48. Guibourdenche J, Frendo JL, Pidoux G, Bertin G, Luton D, Muller F, Porquet D, Evain-Brion D: Expression of pregnancy-associated plasma protein-A (PAPP-A) during villous trophoblast differentiation in vitro. Placenta 2003, 24:532-539.

49. Proctor LK, Toal M, Keating S, Chitayat D, Okun N, Windrim RC, Smith GCS, Kingdom JC: Placental size and the prediction of severe early-onset intrauterine growth restriction in women with low pregnancy associated plasma protein A. Ultrasound Obstet Gynecol 2009, 34:274-82.

50. Sahraravand $M$, Järvelä IY, Laitinen $P$, Tekay $A H$, Ryynänen $M$ : The secretion of PAPP-A, ADAM 12, and PP13 correlates with the size of the placenta for the first month of pregnancy. Placenta 2011, 32:999-1003.

51. Odibo AO, Zhong Y, Longtime M, Tuuli M, Odibo L, Cahill AG, Macones GA, Nelson DM: First trimester serum analytes, biophysical tests and the association with pathological morphometry in the placenta of pregnancies with preeclampsia and fetal growth restriction. Placenta 2011, 32:333-338

52. Frendo JL, Vidaud $M$, Guibourdenche J, Luton D, Muller F, Bellet $D$, Giovagrandi Y, Tarrade A, Porquet D, Blot P, Evain-Brion D: Defect of villous cytotrophoblast differentiation into syncytiotrophoblast in Down's syndrome. J Clin Endocrinol Metab 2000, 85:3700-3707.

53. Guibourdenche J, Frendo JL, Pidoux G, Vidau M, Luton D, Giovagrandi Y, Porquet D, Muller F, Evain-Brion D: Trophoblast production of a weakly bioactive human chorionic gonadotropin in Trisomy 21-affected pregnancy. J Clin Endocrinol Metab 2004, 89:727-732.

54. Handschuh K, Guibourdenche J, Guesnon M, Laurendeau I, Evain-Brion D, Fournier T: Modulation of PAPP-A expression by PPAR $\gamma$ in human first trimester trophoblast. Placenta 2006, 27:S127-134.

55. Sebire NJ, Fowler D, Roberts L, Mahmood S, Nicolaides KH: Trophoblast proliferation is increased in chorionoic villi from pregnancies with fetal trisomy 18. Placenta 2000, 21:584-586.

56. Wright A, Zhou Y, Weler F, Caceres E, Kapidzic M, Tabata T, Kahn MM Nash C, Fisher SJ: Trisomy 21 is associated with variable defects in cytotrophoblast differentiation along the invasive pathway. Am J Med Genet 2004, 130A:354-364.

57. Poon LC, Chelemen T, Minekawa R, Frisova V, Nicolaides KH: Maternal serum ADAM 12 (A disintegrin and metalloprotease) in chromosomally abnormal pregnancy at 11-13 weeks. Am J Obstet Gynecol 2009, 200:e1-e6.

58. Pidoux G, Gerbaud P, Cocquebert M, Segon N, Badet J, Fournier T, Guibourdenche J, Evain-Brion D: Human trophoblast fusion and differentiation : lessons from trisomy 21 placenta. Placenta 2012, 33:S81-S86.

59. Huppertz B, Ghosh D, Sengupta J: An integrative view on the physiology of human early placental villi. Prog Biophys Mol Biol 2014, 114:33-48.

doi:10.1186/1477-7827-12-129

Cite this article as: Leguy et al:: Pattern of secretion of pregnancyassociated plasma protein-A (PAPP-A) during pregnancies complicated by fetal aneuploidy, in vivo and in vitro. Reproductive Biology and Endocrinology 2014 12:129. 